\title{
Two Faces of Norah Jones: A Perspective from Ukraine
}

\author{
Danylo Il'nyts'kyi \\ Ukrainian Catholic University
}

Translated from Ukrainian by Hanna Matsiuk and Julie-Anne Franko

Emendated by Ksenia Maryniak

PROLEGOMENA

Listening to and evaluating the music of American singer Norah Jones, or of any other musician, fans and ordinary music lovers in Ukraine take a dual path. First of all, like any listeners in Britain, Austria, Japan, Argentina, Croatia, or Australia, they are consumers of a musical product, which is transmitted instantly throughout the planet by the global music network on different platforms. On the other hand, there are listeners who are more than just consumers-those who take their reception of artistic works seriously and passionately, whose perceptions are a fascinating combination of sometimes whimsical, sometimes strange layers. The layers occur between what has been heard before and what is sparked by the newly heard. Such listeners effortlessly interpret what they hear, vacuuming up important reference and fulcrum points for themselves. One could say that they engage in "cultural parapraxis" — clarifying and expanding the Freudian slip, in other words.

This essay analyzes and represents the cultural-historical underpinnings, senses, and methodological milestones that would characterize the given context. It comprises a specific combination of discourses with a unique, bipartite focus-one which originates from Ukraine and, on the other hand, from the author's personal experience. In effect, we have an interesting but likely a wholly organic and even ordinary process: the creativity of a musician from another country brings its own mood, style, and integral dimensions that are integrated with the culture of the recipient-thus changing him, perhaps modifying him and in any case expanding him. And then the focus of one's national or occasionally local culture acquires a different dimension as the current music of another 
culture becomes the focus and the prism into which one is momentarily transformed, considering commonplace cultural representations. One's focus, of course, is one's own axis-cultural, sectoral, and personal. Having wandered into this given perceptual landscape, the creative product of a musician from another country seems to undergo a kind of test: Will it be accepted? Will it find an intersection point? Will it resonate?

The present essay is a testimony to both approaches; a testimony that Ukrainian culture, specifically personified by the author of this text, is open and available to receiving current global processes in music. But it is also a testimony of the author's measurement of the artistic vision, musical style, mood, and internal dimensions of Norah Jones's music against the author's familiar and organic cultural, artistic, musical, and literary experience.

Another significant aspect of this essay is its classification in terms of scholarly field or mode of expression. It must be admitted that the infrastructure of music criticism and essayism on musical topics is not developed very well in Ukraine today. I am not speaking about academic musicology—an established and active professional field that is advancing within its given institutions and environments. Rather, I am speaking about the more informal, occasionally more lively or, perhaps, I would say, more jumpy expression of music reviews that is supposed to provoke conversations, create opportunities for debate, anchor the polyphony of world music in this country, and associate its given manifestations with concrete national cultures - not through any methodological-analytical comparison parameters but through actual live reception.

Thus, having decided to implement my own receptive impulse concerning a given period of Jones's creative endeavour, for my part I modestly wish to create-or at least promote the potentiality and importance of - a conversation in Ukraine about pop music today, and possibly confirm whether there would be someone to have this conversation with. I want to develop and legitimize the potential of not necessarily professional musicological conversations about music (as tautological as that may sound), but the conversations that could be had among people outside the field.

Among other sources, my inspiration came from Ukrainian writers and essayists of the interwar period in a variety of cities in what today is Ukraine, who had no qualms about freely expressing their opinions, essentially about any cultural events or phenomena. The discourse of public opinion at that time in my hometown of Lviv-a city at the crossroads of different traditions, a charming city with a unique artistic atmosphere-was a particular inspiration for me. This is not, however, an attempt to bring back those times, nor is it a wholesale attempt at mimicking some opining strategy. Rather, I consider it a kind of reincarnation of the need for unfettered subjective and reflective expression, which today, given the prevailingly 
superficial, mostly promotional, or strictly informative nature of information about musical products, is unquestionably lacking.

A number of years have passed since this essay was written and originally published in Ukrainian. Thus, today's version essentially represents a certain bygone time and space; today, I would be writing about Jones in a totally different way. I cannot know how readers will react to these English-language musical reflections. This preface could be even longer and the text itself could be correspondingly annotated, but my biggest hope is that irrespective of the allusions, connotations, and parallels that were significant to me during the original writing, they will not require annotations and this text will be of value above all due to the interest it sparks in the internal dimensions of the music, in the more or less existential and stylistic-expression issues that it provokes. And if I refer to this or that quote, this or that reflection or experience-that they will not necessarily require looking the authors up in an encyclopaedia; rather that their opinions and experience will be in themselves important beyond any given context.

The original essay comprised twelve chapters. ${ }^{1}$ The present version consists of the last third part of the text. At this point, any aesthetic excitement regarding Jones's first musical stage has already passed. Instead, the focus has shifted to contemplating the stylistic boundaries of her musicianship and the collateral effects of this process.

Lastly, I would like to say how pleased I am about this publication and sincerely thank my colleagues Hanna Matsiuk and Julie-Anne Franko, who translated it. I hope they will be pleased, too.

For Liuba and Pavlo, to whom I am much obliged...

\section{INTRODUCTION}

Tomorrow's fans of Norah Jones will not hesitate to accept her as a multistyled musician with an evolving and versatile creativity. When one pronounces the names of "Edith Piaf," "Billie Holiday," or "the Beatles," the time and distance of their musical journeys allow us to simply refer to them by name while the entirety of their context(s) is understood; we know, for

\footnotetext{
1 The original Ukrainian-language text was published on 16 January 2016 in the electronic magazine / $A$ :/ by Collegium Musicum and subsequently reprinted in the collective work Muzychna faktura literaturnoho tekstu (Musical Texture of Literary Texts, 2017), which is part of a larger inter-media scholarly project run by Svitlana Matsenko (Ivan Franko National University of Lviv, Ukraine). Reprinted with permission.
} 
instance, that there are two faces to the Beatles-equally interesting and important, but different. For those living in the time of Jones, as we experience her music as an evolving process, our aesthetic reactions to her work are not quite the same as to that of the above-mentioned musicians; instead, our aesthetic reactions are to the nuances in the artist's change.

When an artist releases a new album and it is quite different from their past work, we perceive the transformation and connect to it according to our own tastes. Our relation to it is relative to our own personal affairs, thoughts, key moments, evolution, specific changes, experience of contemporary eras, and layers of understanding of events and of people. Artists may understand, albeit not to what extent, that their work bears more than just the music: it can be a companion, bystander, friend, counsellor, or private interlocutor. It offers a remarkable way to go deeply within oneself-a form of therapy, a search for spiritual balance, a wish to recall, revive, or awaken something. Furthermore, our taste is different when we connect to creative work that was lived/written/played before we were born. We plunge into the past and feel a unity with the author/performer and greet them in that world (or pull them into this world), hoping to cheer them with our aesthetic perception"getting it," feeling, or comprehending something.

The motivation to write and reflect upon Norah Jones came from the impact that her last two albums had on me-or, more specifically, from the impact of how her newer albums changed to a format-oriented, more standard presentation that differed from her earlier releases. Notably, my impressions of her earlier work would not dissipate, not even in the contrasting midst of her later songs.

BACKGROUnd: THE TRUTH OF SUbJECTIVE EXPERIENCE

But it's not too late,

Not too late for love.

"Not Too Late"

It started with the Foo Fighters' song "Virginia Moon"; the boys performed it with Norah Jones's voice echoing, resonating in the background. It is one of those cases when the back-up vocal is more interesting than the leads. It is back there, hiding, as if beckoning your imagination-or perhaps hiding because it is refraining from letting itself out from the background into an independent sound. Just the same, you find yourself thinking of "Virginia Moon" as if it was Jones's song. On the basis of this one song, and then a duet with the Foo Fighters, you become completely infatuated in this first taste of artistic spice. You like Norah Jones, and you wonder and anticipate: where will she go as a solo artist? Because she will go somewhere, and in this 
anticipation is the intuitive understanding that it will be somewhere good. At the same time, intuition at a more conscious level guides you not to rush into listening - not out of willfulness or laziness but because you want to savour it. You want to listen to this music the way the Ukrainian writer Andrii Sodomora rereads his favourite poetry: by opening a book, reading a line, and closing it. You want to sit with this line a while, wishing for it not to be influenced by the layers of what is to follow. Your intuition tells you to wait in anticipation of the musical feast like you waited for sweets at home during the holidays, back in your childhood.

In listening to Norah Jones's album Not Too Late (2007), there was a feeling that each song is an entity unto itself. You add it to your list of albums that have no "sappy" songs or songs that fade away into the night. And from there, you put on her first album, Come Away with Me (2002), which seems to be even more resonant. A successful debut album, it won a number of Grammys-likely because of how balanced the grounded and the personal creative work integrated with one another. $[. . .]^{2}$

You become aware of the artist's talent and musical maturity but only intuitively, because you concentrate more on subtly nuanced kernels that stimulate your taste, already resonating with what has been. And in the end, you find a common language with the album Feels Like Home (2004).

So, this is what is called a musical discovery. The rock bands I have heard over the last few years (Nickelback, Daughtry, Coldplay) seemed to be very format-oriented compared to the conceptual rock of the 1960s and 1970s (The Beatles, Pink Floyd, Led Zeppelin, Jethro Tull). From the realization that such a feeling could be embodied on earth, that such a style exists, it was elation, a feeling that I had been gifted something (like on holiday) and a wish to keep this music to myself. It was good to be with it alone, unshared. There was no desire to talk about Norah Jones, not about her or her music; no desire that she be liked by anyone else.

One of the effects of such a musical discovery is that a kind of live discussion with the singer unfolds, and you find a common language. Gender and age do not matter. The words rise up from the recording, your perceptions resonate with it, and it feels like a real conversation. The message is received, without any boundaries between the imagined and the real, and with no territorial or language barriers.

Thus, Norah Jones is interesting for me not as a real person but as an artistic substance. It is such an effect that you even do not want to know about the characteristics or details of the real person-the author and performer of the songs-because the image and feelings created by your fantasy while listening are more interesting than the real person. Though,

2 Here and everywhere, ellipses in brackets mark omissions from the original text. Ellipses without brackets are preserved from the original essay. 
too, the opposite is true: there is a desire to meet and converse with the author of such an interesting and unique artistic world, to ask about their journeys into stories, into the metaphysical.

As with any unquestionable artistic occurrence, the songs of Norah Jones need to be absorbed not with noise and agitation but in silence. It is a place that needs direct communication. Like conversing with God, so too is it conversing with an artist-most fruitful when there is silence, direct contact, and the force of kinetic fluidity. This is because art is a special mediator in our conversation, maybe even in our contact with God.

My listening to Norah Jones coincided with a deeper understanding of the Ukrainian poet Bohdan-Ihor Antonych's artistic world. When Jones sang "Take Me Away" (Nightingale), it resonated with Antonych's harmonic feeling of death: waiting for death is not fatal, it is a greeting, "the last chord of harmony" (Antonych, "De morte, IV"). I had felt it, and this feeling strengthened how I wanted to unite with nature, dissolve in the air, unite with the air, and disconnect so that God can "take me away." Art proves that death is a transition and harmony, not fear and an abyss. As well, it reflects how we lived and what we lived for.

While listening to Norah Jones, you do not feel the fear of death. On the contrary, it seems something organic. Birth, harmony, the songs of Norah Jones, death-are on the same continuum, even synonymic phenomena. And note: this continuum is inviting! The songs give you the subconscious effect of feeling other states. You feel like you were there and then returned. The songs give you peace, transferring the knowledge of harmonic circulation to your life that goes from one sphere to another. In this, the fear of time is overcome. As in Taras Petrynenko and Tetiana Horobets"s song, "Only a song can stop time for us, / Time that runs so fast from us."

While listening to Norah Jones, you feel free. Every person is meant to be free. But people often invent and create barriers for themselves, some inner imprisonment, enslavement, prejudice, stereotypes. While Norah Jones's song reverberates, you feel that you are expanding and rising up to the sky; you become weightless and do not touch the ground. It is the feeling of freedom, when you do not feel time and volatility of life. It is the art given by God and aiming to return to God.

I watched a recording of one of Norah Jones's concerts from New Orleans with my one-year-old son nearby. Watching too, he quietly concentrated on his toys, and from time to time he gave up his games to look up at the screen and then hide somewhere. But he was particularly attentive at the beginning; he watched, mesmerized. It was a testimony not only to his musical taste but to Norah Jones as well-a testimony to the curiosity of those who feel the world in a most subtle way. [...] 


\section{THE “28-YEAR” BOUNDARY AND THE CHILD IN CREATIVITY}

Like the desert waiting for the rain

Like a school kid waiting for the spring

"Turn Me on"

They say that a person has a transition period every ten years or so. We often hear from older people about these transitions, which are of a psychological and physical nature. It would be appropriate here to recall the Ukrainian author Oksana Zabuzhko's study Shevchenko's Myth of Ukraine regarding the psychological basis of anniversaries as part of the civilizational cycle of human existence: "Each anniversary has the indisputable attribute of circularity, mythology, temporality, and has deep ritualistic meaning" (Naidiuk 43).

Perhaps the most significant transition is the one from the young adult years to the so-called adult world view. And without a doubt this transition can be considered to occur at the crucial watershed years of 27-30. Why crucial? Because it is the first awareness of how little life experience there has been and that it is up to an individual to do something about it. This entails even the process of how one takes it in, how one lives with it. These times are particularly noticeable among artists; some of them change distinctly and then there are those who are completely reborn. "It seems to be an age when everyone goes through changes," said Norah Jones on turning 30 in an interview dedicated to the release of her album The Fall. "All my good friends have [changed]. Everyone's either breaking up or getting involved or married or having a baby" (Gardner).

It can also be called the most important period because for many it ends with death. Perhaps that sounds too pessimistic. Let me put it another way: it ends on a road to somewhere far away and undoubtedly higher and deeper, like the roads taken by the Ukrainians Antonych, Vasyl' Symonenko, and Hryts'ko Chubai, by the Americans Jimi Hendrix, Janis Joplin, and Jim Morrison, and by the Russians Mikhail Lermontov and Sergei Iesenin. Perhaps a more concrete example would be the English singer Amy Winehouse, who died at the age of 27 , because she was our contemporary. Another example that comes to mind is the 35-year-old genius Wolfgang Amadeus Mozart. Or the Ukrainian poet Ihor Kalynets', who continues to work fruitfully but became silent as a poet at the age of 40. Among other things, his is an eloquent example of the courage it takes to openly express how the poet within oneself has become silent.

But just the same, 28 is still young. I recall that someone once said that artists do their best before they turn 30. Is that true for every artist? For instance, the solo creative work of each Beatle is not as interesting as their mutual and sometimes conflicting creativity. The Ukrainian scholar Ivan 
Luchuk observed that most manifests are created at a young age (361). As is evident in world art, this is true of more than just manifests. Norah Jones is a young spirit in a variety of forms, yet still proficient at a very high level of performance. This is unique but at the same time typical of performers and bands when young people can deliver their world and feeling with technical dexterity. Here I compare Norah Jones to The Beatles and Antonych, whose poetry is young in essence and yearning, but not by the character and quality of expression of their yearning. Regardless of era, these young-yet-mature artists, who love, suffer, think, and worry, are especially filled with spiritual resonance, which they can masterfully put into writing, singing, or playing.

If we speak about Jones's first three albums, she is fixed in youth, which the singer herself as a living dynamic-entity can already accept with detachment. Such a detachment was noted in Antonych, who said it was due to the law of receptive aesthetics: after finishing a composition, the author becomes its perceiver, or even its critic ("Iak rozumity poeziiu" 558).

It is important that in the face of her musical grounding, Norah Jones did not lose her youth. It is the scent of spring. As a good perfume completes the essence of spring with scents of bloom and grass, so does the scent of young music rest upon the visual and aromatic scenery, completing its landscape with sounds. The music of Norah Jones has this scent of youth; it is clear, selfsufficient, and non-intrusive. And it does not matter that she is a woman. The same is true of boy-bands that teem with youthfulness and render the atmosphere of youth-like it was with the Foo Fighters. "Virginia Moon" is a song where the voices of young men and women combine in their youth. Here the artistry renders a friendship between a boy and a girl during this short span of time in their existence. It is not something flirty that will transform into falling in love, neither is it a business relationship; it is a free, self-sufficient, and equal period in the times of students' lives.

Youth is a special period of creativity, when one still has a child's world view and its feeling of being young but is mature enough to put them into adult forms, to make this feeling civilized and accessible to the world's majority-to adults. On the other hand, youth not only preserves childhood, it prolongs one's stay there. There is a specific difference between adult and young perspectives. In youth, one continues to see the world more openly, as a child does. We can find this specificity in Antonych's creativity: he continued to drink the hop of the world, just as he did in his childhood. Youthfulness is significant because it is a conscious childhood. An individual realizes his or her excitement and feels better, feels happy, and even happier when able to put this feeling into some form of art, which means they share their discoveries with others. That is why so many artists who passed away in the age of potential transition remain pure for fans; they maintained a line of creativity which was not subject to change. 
And that is why when I talk about two faces of Norah Jones, it is about the inevitable and the distinctive difference between these two faces, regardless of their common ground.

\section{Two FACES As a PHENOMENON}

You are not my friend,

I cannot pretend that you are.

"Not My Friend"

The Ukrainian artist Volodymyr Lasovs'kyi once wrote about his colleague Antonych that each artist has two faces. That is to say, the real person and the persona of their artistic creation are very often quite different-though one lives in the other and one collaborates with the other. As such, an artist is human on the one hand and an art entity on the other, not always understanding or knowing what is transpiring with them as they create, and far from being able to control what happens to their creations once they have been released. This is not in reference to the trivial things such as advertisement, CD sales, charts, and the like but rather how the work is received by its audience: what worlds it creates in them as they listen, and how the essence of those worlds later contributes to influencing the essence and experiences of the audience.

The two faces have different levels of being. There is a line between the person and the art entity. And what is two-fold can become three, with a line drawn between the person, the brand, and the entity - the entity of being a poet, a composer, an artist. "Norah Jones is not a brand," she declares, stating the natural intention of her music's development. And we are left to think about it: which one is this Norah Jones who is making the declaration: the person, the brand, or this art entity?

There are stages to creativity, and they have different faces. A person changes and can do nothing about it. Do these stages with two faces exist only for us or for the performer as well? Do they see one thing and we another? We can say only one thing for sure: if we were to imagine speaking about Norah Jones's music in her presence, we would not be speaking about her as a physical entity but rather about the face of the world she created. This is the world given to us as her audience; it becomes our perception of her music. As such, this face gives up the right to ownership of this part of the material. Here, the metaphor of children's single-faced creativity applies: a child fully lives his or her life. Here is an example of how Norah Jones distinguishes her later self from her earlier self: "But I'm a different person from the one who made Come Away With Me. I feel as if I'm entering a new phase" (Thrills). 
The Ukrainian author Vasyl' Stus wrote a piece about the poet Pavlo Tychyna. In his epigraph he recalls an Albert Camus quote: "Any artist who goes in for being famous in our society must know that it is not he who will become famous, but someone else under his name, someone who will eventually escape him and perhaps someday will kill the true artist in him" (Stus 429; Camus 9-10). I will not dare to apply this statement to understanding the essence of Norah Jones's changes. But if I were to extract the most positive and creative theoretical content out of it, I would stress that the work lives its separate self-sufficient life-which perhaps is even more important. Here is what Bruno Schulz wrote: "As a matter of fact, reality does not exist. There is only one truth and one reality-the one created by the artist" (Khtsiuk 45). For some, perhaps, this thinking is too radical. The Ukrainian writer, translator, and antiquity expert Sodomora exemplified this: earlier in life, he could not go to Greece to see everything with his own eyes, so he recreated Greece based on a predisposed understanding. Later, when it became possible for him to go there, he did not want to. Because the image of Greece that he had been creating throughout the years based on imagined constructions became more important to him than the possibility of having real impressions. It had become more aesthetically complete.

In the case of Norah Jones, it is a demonstrative example when the external image of her face reflects her inner world and vice versa. In the end, when the music changes, the face changes, such that new music cannot exist in the face of the old, or the old in the new. Without trying to state an absolute truth about the real face of the person named Norah Jones, in recalling her original internal dimension as an artist, we cannot help but notice the very distinct correlation between the internal and external face. This changes with the second face, the difference being that while in her first period her internal creativity dominated and the external was an organic reflection of this, her second period saw the external face gain the right to be equally dominant, as if by its apprehending essence.

So, do we wish to declare that the image of an author based on their works is what prevails? As the contemporary Ukrainian author Iurii Andrukhovych did in his novel Twelve Rings by showing his understanding of Antonych based on impressions from Antonych's poetry? Perhaps in Norah Jones there is more harmony, and the two faces are her stages, her periods, the conflict of two beginnings in one body, her change that started from transition... 


\section{THE FALL-THE FALL OR THE TRANSITION?}

Round ' $n$ ' round

Carousel

Has got you under its spell

Moving so fast, but

Going nowhere

"Carnival Town"

While listening to The Fall (2009) you cannot but feel that it is a different album. Later on, after Little Broken Hearts (2012), we understand that The Fall is the transitional album, and at the same time the transitional stage for Norah Jones. The first courageous albums were made differently. The new ones replace what was previously written on her pages, so her new messages in her old notebooks can be perceived as a palimpsest.

In Young Blood, Jones sings about young blood and young bones, chasing away the old ghosts ("old ghosts go home"). Is that regarding her musical renewal or her personal change? And what is the character of this change? The Ukrainian writer Ostap Slyvyns'kyi once aptly noted the specificity of transitions in world view and ideology: if you stand in the middle of a change's sphere, you can more or less keep your balance; but if you go to an extreme edge, it often happens that you can wind up shifting to another extreme edge (Slyvyns'kyi). That is why Jones's creative transition is partly a mystery: because The Fall seems to be a great shift to the middle, it is not yet extreme. It is only in Little Broken Hearts that there seems to be a leap to that edge. The album resembles the ripping off of a band-aid; it is a mixture of feelings that stir something different about what is coming. It is an anticipation. And in time, this anticipation needs to be filled with something. It is a transitional stage, which can seem to be endless. But what is the disease and what is the cure-the first or the second period of Jones's creativity? For some, perhaps, it is the first one; for others, it is the second.

It is a transition into a different mood, an adjustment into a different view of oneself and of the world [...]. She sings, "I wouldn't need you to love me" and similar "destructive" things. Is this based on something? On her previous period in life? In her first albums, the mood and the emotional settings of the lyrics were harmonious: the relatively fast rhythm of the sounds in "Not My Friend" does not repel but rather attracts, and the key words in this song are sung very warmly. However, in "I Wouldn't Need You" there is the antonymic "but I do, so come back" and "you'd know I need you to love me." Also, in "Waiting," the calm rhythm coincides with the words "waiting for you to come home." If we were to speak about the aura of the songs, it starts to reflect a more visceral level of our feelings. 
The style of The Fall resembles the style of the previous songs. It is as if they were recreated in a different language, a "language-lite" if you will, one that is easier to take. The means become simpler, like the transition from a piano to a synthesizer. The voice is underscored with sound effects, but this is not conceptual: it is just shading, cosmetics, and adornment. Sometimes true beauty has no makeup, dyed hair, or polished nails. But there is something seductive about makeup and adornments; it is a popular effectand in this case, a sound effect. [...]

So, does it mean that The Fall is an adaptation period for audiences as a prelude to the album of 2012? Its fullness is organic, as it is impossible to hide what comes from the heart. Is that a reflection of a state of mind or the strategy of building an image and style of the performer? Or it is just a whim? But since it is just an adaptation, it keeps to the original. And even here Norah Jones's soft and warm voice still resonates. We feel her previous creativity echoing the electric acoustics and lyricism as before. Even though the song "I'm Waiting for You to Come Home" has shifted to something more severe and demanding, it is still modest and respectful. We feel the former Jones here. Some of the songs possess the character of her previous style, such as "December" and "Back to Manhattan," while others absolutely do not, such as "Chasing Pirates." The majority of the album, however, is filled with the other Norah Jones-the one with the drive and the-so to say-electric electricity.

The Fall is urban. Its mood is very post-My Blueberry Night. In its most interesting songs - "Waiting," "Back to Manhattan," "December," and "Man of the Hour" - the album continues to spread the city aura established in the calm atmospheric My Blueberry Night film of 2007 (dir. Wong Kar-wai). The urbanism in these songs is of a slow, private New York, where the external rhythm of its life diverges from the internal one. This is one of the important characteristics of her musical transition. It is what is left from the past, which we feel most distinctly in "Back to Manhattan."

Many people want to go to New York, for "New York" functions as a kind of mythological topos. People imbue it with the poetics of the romantic. But their imagination and desires speak louder of it than New York does for itself. For some, it is the symbol of a certain status: not material but intellectual, of culture, and, most of all, of a mindset. "New York City has always been a larger-than-life, half-mythical place..." says the collection Poems of New York, published in 2002. It is called the "greatest of the cities," and the poets in this collection are those who love and have loved New York, a little or a lot, from near and far. In short, New York is everywhere (Schmidt, blurb).

But there are other points of view. Larysa Krushel'nyts'ka, a Ukrainian who came to visit her friend, does not hide her skepticism: "Liasia [as she's called] lives in New York. In this dreadful city which is like most other big 
American cities but so idealized by the Americans" (226). Her friend lives in the centre of New York, on a street parallel to Broadway: "And from her balcony Liasia sees all this hopelessness, from the architecture to the street of dull old buildings and newer ones of different heights and shapes. In the afternoon, the street and Broadway are covered with trash, but luckily she cannot see this trash from her balcony" (Krushel'nyts'ka 227). She also mentions Andrukhovych in this work-which brings to mind his afterword to a book by Lidia Stefanowska, Antonych: Antinomies. Andrukhovych reveals how he was shown "the gorges of New York, and only there [he] understood that some of the poems in Antonych's Rotations are not poetry written about just Lviv, or moreover Vienna" (299), but that Antonych's work is universal, that some of his impressions of Lviv's and Vienna's cityscapes may be still be just as filled with trash and have the features of a truly apocalyptic city as has the great city of New York, although he had never been to New York. The external reality changes, but the essence of the city remains the same.

Krushel'nyts'ka also wrote about "the inner emigration." Norah Jones is not from New York; it is not her native home. But can New York be native to anyone? Is there a need for it? And is it even the right question? Anyway, her American upbringing was in Texas, but her inner upbringing, and her view on Manhattan, even if it is dirty or a small corner of NYC, is a personal and private experience, where tropos is more important than topos. To me, Jones's "Back to Manhattan" seems to be a public conversation about New York, with particular place for mythological topos. But on the other hand, it is still a private experience, with memories and real feelings that constitute our lives. Once again, I return to Antonych and Andrukhovych:

Antonych is very universal, he is like free gas that fills everything-from the void of the abandoned buildings in Novytsia [the village where he was born] to enriching Brownian rambling through the narrow streets of New York, instantly combining the province and centre, micro and macro. (Andrukhovych 299).

This can be applied to all "city creations," particularly to Norah Jones's private-universal Manhattan.

\section{Change: The Second Face of Norah Jones (LITTLE BRoken HeARTS)}

So if you never come to me

You'll stay a distant memory

"Don't Miss You at All"

In The Fall, we can still decode and reconstruct what was recorded on Jones's 
palimpsest of earlier times. In Little Broken Hearts, we merely know that something was before-but what? The power of the low tones and the ease of the high tones in "Miriam" tease our memory. And the drama of its sounds recalls the lyrics of Ukrainian songs like the Ukrainian rock band Komu Vnyz's "Pryvyd z haiu" ("Ghost from the Grove") and "Vyidy, zmuchena liud'my" ("Come out, Woman Weary of People"). The echo of the electric piano in the epilogue provokes our imagination, successfully reminding us of things as they were before. For the sake of the song "Miriam," we skip the middle of the album and go from the beginning to the end. This song is beloved by the young women of Lviv, perhaps as a passage toward new kind of womanhood for them.

New? Before the "new" album Little Broken Hearts, there were seven whole years in Jones's creative activity, from 2002 to 2009. "No," "No way," and "I don't get it" - these were three phrases to express my reaction to the drastic change of this album, even taking into consideration the change that occurs at the "28-year" boundary. But to call it spiritual death would not be correct, as doing so would be one-sided and superficial...-it is not by coincidence that there is an ellipsis here... This section of my essay will not proclaim its vision. All it can do is shrug its shoulders and add these three dots...

In reading Norah Jones's interviews, one notices that they are filled with an irritation and desire for her audience to turn this new page with her; and one should be aware that this is human. On the one hand, we do understand Jones's desire for change, which is natural for everyone and inevitable. On the other hand, we remember that her early works live their own life. The later Jones does not have influence over the works of the earlier Jones, and if anything, these later works are somewhat hindered by the earlier ones. This creates an awkward situation over which the author-performer can do nothing, just as we can do nothing about our feelings toward her change. They are two separate processes; the change goes one way, and our reflection goes another.

It is unlikely that we are fooled by our senses. In the beginning, we witnessed a harmonious and calm Norah Jones, speaking about Lee Alexander, humbly performing on stage in modest attire. And then, there was some kind of explosion that blew away her image of always being sweet, that showed everyone something else, as if she wanted to free herself from shackles, to show herself in a different and more radical light.

Clearly it is primarily an inner need, her wanting to emerge in the form of this appearance (Sisario). The cover of Little Broken Hearts is created in the same style as the poster for the film Mudhoney (1965, dir. Russ Meyer), and Norah Jones copies Lorna Maitland's looks, from Lorna's hair and makeup to her glances. But even so, Jones remains herself. It looks like ABBA's song sampled in Madonna's "Hung Up." But in her case, Jones 
definitely has more intertextuality than the pop diva Madonna. But the reasons for the pop diva's need for this send-up, spending huge amounts of money for the rights to get the song - to take advantage of what is already known-cannot be explained by a need to make more money, her tiredness, or her whims. Perhaps such needs are not as organic to Jones, but even if she has them, are we being too critical? There is nothing more natural for a creative individual than to turn a page when time is right, to rip off a bandaid, to contest the static, even when it means contesting oneself. Especially when the contest is against someone else occupying that individual's name, someone who will sooner or later steal that inidividual's identity? (Camus) If so, then this is courageous self-preservation. Has Jones really come here to find herself? Even if we are not accustomed to this second face...

And it is the first thing that catches the eye. Significantly, it is the other image that this one begins from. Like it or not, you see it right away, it strikes your eye. It is like a preamble to music, a warning, a manifest. A program. The subconscious tells you this change is somehow deceptive... We all know that "stars" like to change their image. It happens all the time. Viktoriia Malektorovych, the Ukrainian actress of Ukrainian TV series Tsarivna (Princess) and of Mykhailo Illienko's film S'omyi marshrut (Route 7) and of Oles' Ianchuk's film Neskorenyi (Unbroken) now starts in popular Russian TV series. And even the legendary Larysa Kadochnykova, who was in the acclaimed Ukrainian classic film Tini zabutykh predkiv (Shadows of Forgotten Ancestors, 1965, dir. Sergei Paradzhanov), we now sorrowfully watch in a pop Russian TV series (is there anything worse than this?). These early roles of the actresses give them a right to act in anything later. It is a conscious step aside from their identities, and the proof of this is in the union of their external personas and their internal emergence in their roles.

The voice of Norah Jones, if taken on a personal level, is a revelation that is characteristic of modern music. And in her 2012 album, it sounds as if someone was being forced to speak words that were not their own. It is like a race car being used for driving to work: an unnatural sound. She sings, taking on the role of short-skirted pop stars in show business, and of the musicians who "accompany" them, going from album to album. And what comes of this? Where once the sound of the race car roared down the tracks, it now restrains itself on ordinary roads. Should this be considered the new sound?

This is how Norah Jones's voice sounds in "Say Goodbye" - starting from a fleshy head voice then descending into a chest voice. Maybe someone else is singing the part of Jones's voice? The same chest voice is used in "Miriam," creating the impression that the queen herself is sitting on the throne, singing... A lady who has already accomplished everything and can sit and give out orders. Are these deep chest voice sounds the shift from her flexible life of a girl to the static voice of a woman? Perhaps my desire to skip the 
middle of the album comes from its static quality. But Jones's youth is fixed, and the effect of returning to it is inevitable for the author ${ }^{3}$ and her audience, to the point of repulsion, which one would like to omit but cannot. It is not about seeing her youth as immaturity but rather as the time of condensed naturalness. "Only song will bring us back / Our youth and our love," sings Petrynenko in a duet with Horobets'.

Let us compare the videos of "Until the End" and "Young Blood." The first is surprisingly expressive, while remaining simple and modest, judging by the standards of the modern video industry. It is just Jones, without any effects; the aesthetics are truthful. No need to show off, just to be yourself, and people will love you. The second video has more movement, more changing pictures, and a tendency to flash a multitude of changes. It is more about the format. Essentially, all the early videos of Jones are simple but deep and interesting, like fairy tales. They have their symbolism, a child's way of building the visual image of the song and no external computer effects. These videos may look cheap from a technical/material point of view, but they are whimsical. ${ }^{4}$ And the whimsy here-is not it a synonym of art?

Going back to the discussion about Jones as a pop-jazz-diva, it is written about her that her first albums are pop albums. To my thinking, it is the opposite; her last two albums are pop. It is a clear step toward the standard. Not like the Beatles, who changed from pop into something experimental. It is not Sting's experiments with folklore either. Ukrains'kyi tyzhden' (The Ukrainian Week) magazine wrote about the sweet image of the early Norah Jones (Synyts'ka). But I would not say so; it is a rather spicy image, and a spicy sound. They wrote that new music has a new sound. But is it a new sound? "A new sound" is too exaggerated. Rather, it is the entrance to another musical paradigm that does not equate to a new sound. It would be too trite and sentimental if I was to say: "Wanted: Norah Jones." But still there is something to it... some trembling for the past... Maybe one could say that it is easy to criticize because the soul of an artist is not so easy to understand. We all want to change and none of us like the pressure put on us by authorities, ourselves, and others. We do not like living by how they see us, but by how we see ourselves. The psychologists and psychiatrists would have a lot to say about this process of creativity.

I wonder how Norah Jones's last two albums $(2009,2012)$ will be accepted later and what the next generations will have to say about them... If we look at classic performers like Eric Clapton or Paul McCartney, we see

\footnotetext{
${ }^{3}$ Most of the songs in The Fall were written by Norah Jones, and in Little Broken Hearts all the songs were written in co-authorship with Brian Burton, known by his stage name Danger Mouse.

${ }^{4}$ Recall the weird Ukrainian prose and its worldwide counterpart, Latin-American magic realism.
} 
different scenarios. There are some pop releases, like Clapton's Pilgrim (1998). McCartney, on the other hand, produces a wonderfully melodic album, Chaos and Creation in the Backyard (2005), although generally his solo creativity is in pop music.

Norah Jones says she does not pay attention to public opinion. But the public is not ignorant. Does she think that her audience will cheer everything? Maybe her new audience will, but you cannot hide her old music from them. And her older audience will perceive the new work through the prism of their longstanding "NorahJonesExperience." If listeners are sensitive and thoughtful, they will live through the works of art together with the author (writer) or performer (musician, singer), recreating themselves within the songs, catching the nuances. That is why when we talk about an artist's change, we mean the kind of change for people who like Jones's early creativity; if they do not accept it, they live it through. I got hooked on the early songs of Jones. They speak through my thoughts and my feelings, and I speak with them. But when I listen to her last albums, I feel a certain dissonance... In Shakespeare's Hamlet, there's a line, "For there is nothing either good or bad but thinking makes it so" (Act II, scene II). The fear of others makes people evil, recognition makes them popular, gratitude toward others makes them kind. Dmytro Bohomazov, a Ukrainian theatre director, says a play is born only when the audience comes to the theatre (Tsyhylyk 25). Even here we cannot avoid the phenomenology: it was the audience that made Norah Jones popular. These were the mutual signs. The audience does not serve only as background and decoration. We know that art produced for the public cannot go on without the public. It's the audience that "makes" art. And ignoring the public, the way actors do in a play, is an effect of the psychology of the creative process: to be with oneself. But there is a paradox here too: because there is the need for an audience, there is an emotional dependence on it.

Now, what happens to Norah Jones's audience when they switch on Little Broken Hearts? Are they as disoriented as bees whose are repelled by cell phone signals?... Again, the pause of an ellipsis. Of course, it is possible to put one's mind to getting used to the music, to the so-called new soundbut the early Norah Jones is the silver, it is like the classics, like blues, or classic jazz, and her songs are far from being too sweet. Of course, Jones's Little Broken Hearts is not the low glitzy pop that is so trendy all over the world. It is still Jones. But we feel the dissonance. It has glitz. So let it be an ambivalence toward her drive to being glitzy. But on the other side, there is a barricade of just not buying it. No wish to listen. No ability to listen...

Properly speaking, when I listen to Little Broken Hearts, I imagine some glitzy blonde, and even the scent of her glitzy perfume reaches my nose. A lot can be discerned from a scent! And music has a scent. Someone once said that the nose is the basis of beauty. I can partially agree, in part because with 
the nose we can distinguish scents, a telling thing in perceiving the world. Scents will let you know whether the person who stands before you is of art or of glitz, if this individual is from country or city, nervous or calm, creative or destructive. It is one of the sharpest senses and it sometimes prevails, telling the truth of essence. "Say Goodbye" depicts the image of a woman: beautiful but haughty, smiling with external warmth but internally cold. The scent of that woman is not appealing; it evaporates, like the aftereffect of bumping into a wall. She wears a dress that covers her neck, not because she is shy, old-fashioned, or afflicted. It is because it retains warmth. And here is where the mask appears... And one more thing: we know from the fashion of late-nineteenth-early-twentieth-century dresses of salon women that the white polka dots on this dress are too small. This means that warmth and austerity cannot co-exist. Were the dots bigger, that would testify to a broader view of the world and of people.

Norah Jones's first albums show us a completely different image of a woman - sophisticated but modest, romantic but deep, tender but far from being sweet. It is smooth and nobly metallic at the same time. We cannot say that Ella Fitzgerald or Billie Holiday were too sweet, and Norah Jones is not sweet, but rather like pure chocolate-bitter, but tasty in its bitterness. Every time we eat it, we forget the previous experience of bitterness and return to the unknown state of anticipation. We have this impression after "Good Morning," which is the most interesting among the first five songs of Little Broken Hearts, and it gives the feeling of a beautiful morning... It should be listened to at the end, to preserve this unfinished feeling-for a future day ahead, a coming day over the horizon, for a new album that hopefully will appear... Every morning we feel this perspective, as we feel it when we taste chocolate, with a sweet and appealing kind of bitterness...

It is the first song that should be listened at the end of the day, to be closer to the fairy tale world of the first albums, before the "after" appears. Before Norah Jones, while still remaining Norah, becomes grownup, more format-oriented, and changes the splash of her young creativity, the best part of her whole chronology.

There are those who say that the time for creativity only happens in one's youth. However, drawing from his own creative experience, the Ukrainian poet Viktor Neborak maintains that poetry is created only when you believe you can change the world. Indeed, when you stop believing, the poetry becomes different. [...] 


\section{Works Cited}

Andrukhovych, Iurii. "Vichno inshyi poet. Pisliamova dlia Lidy i Bohdana." Antonych. Antynomii, by Lidiia Stefanovs'ka, Krytyka, 2006, pp. 295-300.

Antonych, Bohdan-Ihor. "De morte, IV." Velyka harmoniia, translated with foreword and notes by M. Naidan, Litopys, 2007, p. 39.

---. “Iak rozumity poeziiu.” Vybrani tvory, Smoloskyp, 2012, pp. 552-58.

Camus, Albert. "Create Dangerously." Create Dangerously, translated by Justin O’Brien, Penguin Books, 2018, pp. 1-33.

Gardner, Elysa. "For Norah Jones, 30 Is an Age of Change in Her Music.” USA Today, 28 Dec. 2009, https://usatoday30.usatoday.com/life/music/news/2009-1228-norah28_ST_N.htm. Accessed 30 Apr. 2021.

Khtsiuk, Andzhei. "Bruno Shul'ts-zacharovanyi i zvychainyi." Krytyka, nos. 3-4, 2011, pp. 42-46.

Krushel'nyts'ka, Larysa. "Liasia.” Rubaly lis... (Spohady halychanky), L'vivs'ka naukova biblioteka im. V. Stefanyka Natsional'noi akademii nauk Ukrainy, 2001, pp. 226-27.

Lasovs'kyi, Volodymyr. "Dva oblychchia Antonycha." Vybrani tvory, by B. I. Antonych, Smoloskyp, 2012, pp. 683-88.

Luchuk, Ivan. Mystetstvo poetychne $v$ dyskursi ukrains'koi liryky ta pys'mennyts'koi krytyky. Instytut Ivana Franka Natsional'noi akademii nauk Ukrainy, 2012.

Naidiuk, Olesia. "Valentyn Syl'vestrov vidbuvaiet'sia zanovo." Krytyka, nos. 3-4, 2013, pp. 41-43.

Schmidt, Elizabeth, compiler and editor. Poems of New York, Alfred A. Knopf, 2002.

Sisario, Ben. "Mudhoney, Norah Jones and a Vintage Film Poster." The New York Times, 21 Feb. 2012, http://artsbeat.blogs.nytimes.com/2012/02/21/mudhoney-norah-jones-anda-vintage-film-poster $/$ ? php=true\& type=blogs\& r=0. Accessed 30 April 2021.

Slyvyns'kyi, Ostap. "Ponevolenyi i vyzvolenyi rozum: pol's'ki pys'mennyky stosovno komunizmu." Tsykl "Akademriznytsia," Tsentr humanitarnykh doslidzhen' L'vivs'koho natsional'noho universytetu imeni Ivana Franka, 4 April 2014. Public lecture.

Stus, Vasyl'. "Fenomen doby (skhodzhennia na Holhofu slavy)." Vybrani tvory, Smoloskyp, 2012, pp. 429-92.

Synyts'ka, Olena. "Medovyk iz pertsem. Nora Dzhons-sama sobi styl' i napriam." Ukrains'kyi tyzhden', 18 Dec. 2009, http://tyzhden.ua/Publication/4521. Accessed 30 April 2021.

Thrills, Adrian. "Have You Met the New Miss Jones? Norah Goes from Jazz Diva to Rock Chick with New Sound." Mail Online, 26 Mar. 2010, http://www.dailymail.co.uk/tvshowbiz/article-1260674/Have-met-new-MissIones-Norah-goes-jazz-diva-rock-chick-new-sound.html. Accessed 30 Apr. 2021.

Tsyhylyk, Mariia. "Teatr iak vyklyk (interv"iu z Dmytrom Bohomazovym)." Ukrains'kyi teatr, no. 1, 2014, pp. 22-25. 